УДК 371.134:378.1

DOI: 10.37026/2520-6427-2021-107-3-54-59
Валентина ФЕДЯСВА,

доктор педагогічних наук, професор, професор кафедри педагогіки, психології й освітнього менеджменту імені професора $С$. Петухова Херсонського державного університету, м. Херсон, Украӥна ORCID: 0000-0002-8658-1875 e-mail: Valentina.Fediaieva@gmail.com

Віталій ЩЕРБИНА, кандидат педагогічних наук, доиент кафедри педагогіки, психології й освітнього менеджменту імені професора С. Петухова Херсонського державного університету, м. Херсон, Україна ORCID: 0000-0002-5890-7284

e-mail: vitaliysherbina85@gmail.com

\title{
ПЕДАГОГІКА В СИСТЕМІ ПРОФЕСІЙНОЇ ОСВІТИ
}

\begin{abstract}
Анотація. У статті на основі аналізу навчальних програм, посібників, науково-методичних рекомендаиій, архівних джерел розглядається генеза реалізаціі дисииплін педагогічного ичиклу в системі вищої професійної освіти на зламі століть (XX-XXI). Виокремлено такі етапи: 1-й етап - за радянською парадигмою (70-80-і роки ХХ століття), 2-й етап - становлення національної системи освіти (кінець ХX століття), 3-й етап - інновачійний (початок XXI століття). Ця змістова етапність визначається за типом навчальних закладів: педагогічних інститутів, педагогічних університетів, класичних університетів.

Встановлено, щяо в 70-80-х роках ХХ століття педагогічні дисиипліни, педагогічна практика мали безперервний характер, навчальні програми розраховувалися на всі 4-5 років навчання, доповнювалися спецкурсами, які відповідали за змістом актуальним тогочасним питанням навчання й виховання дітей.
\end{abstract}

У статті наголошується, що суттеві зміни у змісті педагогічної освіти відбулися у 90-х роках ХХ століття - за часів реалізації національної освітньої парадигми, зокрема введенням таких навчальних дисииплін, як: «Народна педагогіка», «Етнопедагогіка», «Народознавство» та ін. Укурсі «Історія педагогіки» було посилено увагу до вивчення педагогічних ідей, теорії $і$ практики навчання $i$ виховання дітей на основі історичної традичії.

Науковий пошук засвідчив, щзо в умовах сьогодення в класичних університетах підготовка педагогічних кадрів відбувається на основі нової законодавчої бази України з урахуванням зарубіжного досвіду, вивчення педагогічних дисииплін як за традииійною системою, так і розширенням змістових ліній педагогіки, історії педагогіки через введення до освітніх програм широкого спектру вибіркових дисииллін.

Ключові слова: педагогіка, програма, навчальна дисципліна, освітній процес, заклади вищої педагогічної освіти.

Valentina FEDYAEVA,

Doctor of Pedagogical Sciences, Professor,

Professor of the Department of Pedagogy,

Psychology and Educational management named after prof. E. Petukhov,

Kherson State University,

Kherson, Ukraine

ORCID: 0000-0002-8658-1875

e-mail:Valentina.Fediaieva@gmail.com

Vitaliy SHCHERBYNA,

Candidate of Pedagogical Sciences,

Associate Professor of Pedagogy,

Psychology and of educational management

named after prof. E. Petukhov,

Kherson State University,

Kherson, Ukraine

ORCID: 0000-0002-5890-7284

e-mail: vitaliysherbina85@gmail.com

\section{PEDAGOGY IN THE SYSTEM OF VOCATIONAL EDUCATION}

Abstract. The article based on the analysis of curricula, manuals, scientific and methodological recommendations, archival sources, considers the genesis of the implementation of disciplines of the pedagogical cycle in the sys- 
tem of higher professional education at the turn of the century $(X X-X X I)$. It has been distinguish such stages: 1 st stage-according to the Soviet paradigm and the years of the XXth century), the 2nd stage - the formation of the national education system (late twentieth century), the $3 r d$ stage - innovation (early XXI century). This semantic stage is determined by the type of educational institutions: pedagogical institutes, pedagogical universities, classical universities.

It has been established that in the 70-80s of the XXth century pedagogical disciplines, pedagogical practice were continuous, curricula were designed for all 4-5 years of study, supplemented by special courses that corresponded to the content of current issues of education and upbringing of children.

The article emphasizes that significant changes in the content of pedagogical education took place in the 90s of the XXth century - during the implementation of the national educational paradigm, in particular the introduction of such disciplines as "Folk Pedagogy», "Ethnopedagogy», "Ethnology» and others. The course "History of Pedagogy" focused on the study of pedagogical ideas, theory and practice of teaching and educating children based on historical tradition.

Scientific research has shown that in today's conditions in classical universities training of teachers is based on the new legal framework of Ukraine, taking into account foreign experience, the study of pedagogical disciplines as a traditional system and expanding the content of pedagogy, history of pedagogy through the introduction of a wide range of educational programs. elective disciplines.

Key words: pedagogy, program, educational discipline, educational process, institutions of higher pedagogical education.

Постановка проблеми. Університетська педагогічна освіта покликана забезпечувати формування вчителя, який здатний розвивати дитину, зорієнтований на особистісний та професійний саморозвиток і готовий працювати творчо в закладах освіти різного типу.

Усе це обумовлюється низкою сучасних завдань: зростанням ролі вчителя в суспільстві, що вимагає отримання відповідної вищої професійної педагогічної освіти; виникненням і функціонуванням різноманіття закладів освіти, шкіл нового типу (ліцеїв, гімназій, коледжів, опорних шкіл), зростанням рівня вимог, які постають перед учителем в організації освітнього процесу в них; навчанням учнів в епоху діджиталізації, що спрямовує підготовку вчителя до засвоєння сучасних технологій навчання в умовах нового освітнього середовища, переходу від традиційної до інноваційної підготовки.

Педагогіка як наука і навчальна дисципліна є неодмінною складовою системи професійної освіти викладачів, має свої періоди розвитку, свою парадигму й змістове наповнення і завжди історично була, $\epsilon$ i буде основою підготовки та перепідготовки вчителя в педагогічних інститутах, університетах, закладах післядипломної освіти. Ї̈̈ зміст, завдання, мета, прийоми, форми, засоби, методи відповідали економічному, політичному, соціокультурному розвитку країни, соціалізації дітей та молоді загалом.
Аналіз наукових досліджень і публікацій. Питанням підготовки вчителя в процесі засвоєння педагогіки присвячено низку праць вітчизняних учених сучасності. Це роботи О. Антонової, І. Зайченка, В. Кравця (1996), В. Радула, О. Савченко, С. Харченка, Л. Хоружої та ін. Значущість вивчення історії педагогіки розкривають такі вчені, як Л. Березівська, Л. Ваховський, Н. Дічек, О. Петренко, О. Сухомлинська. На важливості вивчення філософських основ педагогіки наголошують науковці В. Андрущенко, І. Бех, В. Кремень, В. Огнев'юк, С. Сисоєва. Окремі праці присвячені народознавчій складовій педагогіки. До них відносимо доробок О. Руденка, М. Стельмаховича, Є. Сявавко та ін. Розкриваючи досить широкий спектр складових педагогіки, вітчизняні вчені підкреслюють, що педагогіка, історія педагогіки, соціальна, порівняльна, зарубіжна педагогіки є основою професійної підготовки, становлення і зростання сучасного вчителя. Науковці доводять, що зміст, мета, завдання освітніх дисциплін педагогічного циклу на кожному етапі розвитку і становлення системи педагогічної освіти, підготовки вчителя, розвиток педагогічної науки в цьому контексті загалом визначалися суспільними вимогами до освіти, виховання дітей та молоді на кожному історичному етапі розвитку нашої країни, а отже, розгляд цих питань у контексті історичної ретроспективи $є$ конче важливим, актуальним, перспективним. Найбільш повно, на нашу думку, ці зміни розглянуті у фаховій складовій неперервної педагогічної освіти, можливо, через здійснення аналізу наукових праць, програм, підручників, посібників, методичних рекомендацій із навчальних дисциплін на різних етапах становлення педагогічної освіти в Україні. Для свого дослідження ми вибрали період 70-80-х років XX століття і до сьогодення, який визначили періодом на зламі століть (XX-XXI ст.). Це період підготовки вчителя за радянською парадигмою і період незалежності України - підготовки вчителя української школи, провідною ідеєю якої є концепція національної освіти. Таким чином, ми розглядаємо три етапи. За цієї умови слід урахувати, що два останні - це періоди творення по суті нової системи закладів вищої освіти (на зміну педагогічним інститутам «прийшли» педагогічні університети або класичні університети (Вища педагогічна освіта і наука України: історія, сьогодення та перспективи розвитку. Херсонська область, 2010).

Мета статті - систематизація навчальних дисциплін із педагогіки як провідної складової підготовки вчителя у конкретний історичний період на різних етапах шляхом аналізу основних навчальних дисциплін, спецкурсів, зокрема і за вибором студентів задля підвищення ефективності вивчення майбутніми вчителями дисциплін педагогічного циклу в умовах сьогодення.

Завдання наукового пошуку полягали в обгрунтуванні необхідності і важливості реалізації неперервного, цілеспрямованого, послідовного засвоєння майбутніми вчителями основ педагогіки, її теоретичної, історичної, практичної і прикладної складової, які б відповідали потребам суспільного, соціально-економічного, освітньо-культурного розвитку країни і світу, сприяли успішній соціалізації дітей та молоді на різних історичних етапах розвитку країни в контексті історичної ретроспективи. 
Виклад основного матеріалу дослідження. Вивчення програм, підручників з окремих складових (галузей) педагогіки, тематики захищених дисертаційних досліджень свідчить про змінність навчальних дисциплін, курсів, практичної підготовки вчителя у процесі становлення і розвитку системи неперервної педагогічної освіти.

Аналіз підготовки педагогічних кадрів у 70-80-х роках XX століття засвідчив, що навчальна дисципліна «Педагогіка» (1963) (Програми педагогічних інститутів. Педагогіка, 1963) та спецкурси $(1985,1986)$, що доповнювали іiі, вивчалися в закладах вищої освіти на вчительських спеціальностях 4-5 років, починаючи з першого року навчання і завершувалися державним екзаменом. Крім того, викладалося безліч обов'язкових спецкурсів, унормованих лекційними і практичними видами робіт (семінарські та лабораторні): «Введение в учительскую специальность» (1978) - 30 год, «Вступ до педагогіки» (1970) - 30 год, «Педагогіка» (1985) 100 год, «Історія педагогіки» (1970) - 60 год, «Педагогіка школи» (1973) - 50 год. Також студенти вивчали окремі курси: «Генеза й основи педагогічної системи А. С. Макаренка» (1986) - 24 год; «Теорія і практика індивідуалізації навчальної діяльності школярів» (1986) - 20 год; «Міжпредметні зв'язки в освітньому процесі» (1986 ) - 24 год (Программы педагогических институтов, 1986); «Формування комуністичного світогляду учнів» (1985) - 24 год; «Взаємодія державних закладів, сім'ї і суспільства у комуністичному вихованні школярів» (1985) - 24 год; «Психологія діяльності вчителя» (1985) - 12 год; «Методи вивчення особистості учнів і учнівських колективів» (1985) - 22 год; «Методи попередження педагогічної запущеності і правопорушень неповнолітніх» (1985) - 36 год; «Шкільний підручник» (1985) - 40 год та ін. Практично, це була система навчальних дисциплін, які сьогодні ми можемо вважати дисциплінами вільного вибору студентів (Программы педагогических институтов, 1985).

Отже, педагогічна складова визначалася основними навчальними дисциплінами і спецкурсами, методичне забезпечення здійснювалось структурними підрозділами закладів вищої освіти, особлива увага приділялася студентам-заочникам - практично, до кожних із навчальних дисциплін розроблялися методичні вказівки для самостійного вивчення курсу. За даними архіву Херсонського державного університету, загалом педагогічний блок включав - 270 год основного курсу та 276 год спецкурсів, що сприяло формуванню широкого спектру знань із дисциплін педагогічного циклу і давало можливість реалізувати як навчальну, так і виховну компоненту освітнього процесу в школі.

Що ж стосується практичної підготовки цього періоду, то вона відбувалася на кожному курсі навчання за чіткою програмою, затвердженою Міністерством освіти СРСР та Міністерством освіти УРСР (1975). Вона мала свої особливості порівняно із сьогоденням, оскільки інші навчальні дисципліни мали неперервний характер, а студенти з першого курсу перебували в школах на різних видах практики:

1) I-II (III курси) - ознайомлення студентів зі специфікою педагогічної діяльності - пропедевтична практика;
2) II-III курс - літня педагогічна практика в закладах позашкільної освіти та піонерських таборах 4 тижні;

3) III (IV курс) - педагогічна практика в школах, професійно-технічних училищах, дитячих спортивних школах та інших навчально-виховних закладах 6-7 тижнів;

4) IV-V курс - 7-8 тижнів у закладах різного типу, як правило, у старшій школі (Программы педагогических институтов. Программа и типовая инструкция по организации и проведению педагогической практики студентов, 1975).

Усі види практики мали навчальний і виховний характер. Такою структурованою була теоретична i практична підготовка вчителя до кінця XX століття в більшості педагогічних закладів вищої освіти.

Вивчення питання дало змогу констатувати, що серйозні зміни у змісті дисциплін педагогічного циклу відбулися вже в 90-х роках XX століття - періоду розбудови вищої школи незалежної України, самого широкого втілення парадигми національної освіти i виховання, орієнтації України на європейський та міжнародний освітній простір. За аналізом навчальних програм Херсонського державного університету, в цей час підготовка вчителя включала як основні курси з педагогіки, історії педагогіки, теорії і практики виховання, так і нові, що розкривали особливості української національної виховної традиції: «Народна педагогіка», «Народна деонтологія», «Порівняльна педагогіка», «Освіта і Болонський процес», «Сучасні технології в освіті», «Сучасні технології виховання», «Педагогічне краєзнавство» (архівні матеріали, робочі програми кафедри Педагогічна майстерність) (ХДУ, ф. 469, оп. 9, спр. 432,437$)$ та ін. Загалом вони доповнювали базову освіту вчителя (мови та літератури, біології, історії, хімії, математики тощо) та його практичну підготовку. Таким чином, наприкінці XX століття базовими залишаються «Педагогіка», «Історія педагогіки», «Педагогічна майстерність», «Теорія і методика виховної роботи», що доповнювалися курсами, які відповідали профільній професійній підготовці - «Педагогічне краєзнавство», «ІІторіографія історії педагогіки», «Маловідомі педагоги України», «Дитяча деонтологія», «Філософія дитинства», «Дитячий туризм», «Соціальне гувернерство», «Дозвіллєзнавство» та ін. Цей період визначався неперервною педагогічною підготовкою, активною розробкою важливих актуальних спецкурсів педагогічних дисциплін, які поєднували інноватику з історизмом.

Ситуація поступово змінилася після того, як педагогічні інститути й університети отримали статус класичних університетів, що призвело до зміни програм, змісту підготовки вчителя, його практичної підготовки в закладах освіти i, в свою чергу, не сприяло ефективній підготовці вчителя сучасної школи, а саме формуванню в нього основ науково-методичної, організаційно-педагогічної та виховної складових. За проведеним аналізом викладання педагогічних дисциплін у Херсонському державному університеті на різних факультетах ми простежуємо тенденцію до зменшення кількості годин на вивчення дисциплін $з$ педагогіки, хоча вимоги зростають, умови роботи вчителя змінюються, а його фундаментальна 
(теоретична) і практична підготовка стає такою, що не відповідає сучасним вимогам. Такою $є$ ситуація практично на кожному факультеті в системі університетської освіти, де відбувається підготовка за спеціальністю «Середня освіта». За побудованою діаграмою спостерігаємо динаміку зменшення частки годин і навчальних дисциплін, які забезпечують кафедри педагогіки університетів. Такий стан речей характеризує загальну тенденцію вивчення основ педагогіки в класичних університетах за освітніми програмами на різних факультетах.

Водночас аналіз проблеми засвідчив і позитивні сторони цього процесу, зокрема за останні 10 років студенти отримали можливість широкого вибору дисциплін, спецкурсів за авторськими навчальними програмами, що доповнює їх професійну складову. Наприклад, такими є програми, розроблені викладачами кафедри педагогіки та психології Херсонського державного університету, розроблені у 2014 році: «Професійно-етичні основи соціальної роботи», «Методика організації волонтерського руху», «Психодіагностика», «Порівняльна педагогіка в контексті Болонського процесу», «Основи соціалізації особистості», «Технологія роботи соціального гувернера», «Теорія і методика організації виховної роботи у закладах освіти», «Провідні моделі педагогічної освіти батьків», «Сучасні концепції сімейного виховання», «Сучасні педагогічні технології виховання» (Збірка авторських навчальних програм з психолого-педагогічних дисциплін, 2014, 96 с.). Вони щорічно оновлюються, доповнюються і дають можливість студентам вивчати ті курси, які формують практичні навички роботи з дітьми та молоддю в умовах сьогодення.

Дослідження свідчить, що на сьогодні у підготовці майбутнього вчителя мають місце прорахунки, одним з яких, на нашу думку, є недооцінка ролі педагогічних дисциплін у професійній підготовці, що негативно впливає на формування у студентів умінь та навичок здійснювати освітню діяльність загалом - бути викладачем і вихователем.

Практично, за нинішньої ситуації, студенти поверхнево вивчають, наприклад, такий розділ (модуль) педагогіки, як теорія і практика виховання. Повноцінне вивчення курсу дало б студентам можливість засвоїти такі поняття: історія виховання; сутність виховного процесу; складові сучасної виховної системи школи; інноваційні виховні технології; шляхи, форми, методи, засоби, концепції виховання в контексті історичної ретроспективи. Адже саме такий навчальний модуль поєднує в собі педагогіку, методику виховної роботи, педагогічну майстерність, історію педагогіки і сприяє не тільки засвоєнню теоретичних основ, а дає можливість студенту обгрунтувати особливості того чи іншого напряму виховної роботи, шляхи його реалізації за різних умов, прийомів, засобів виховання.

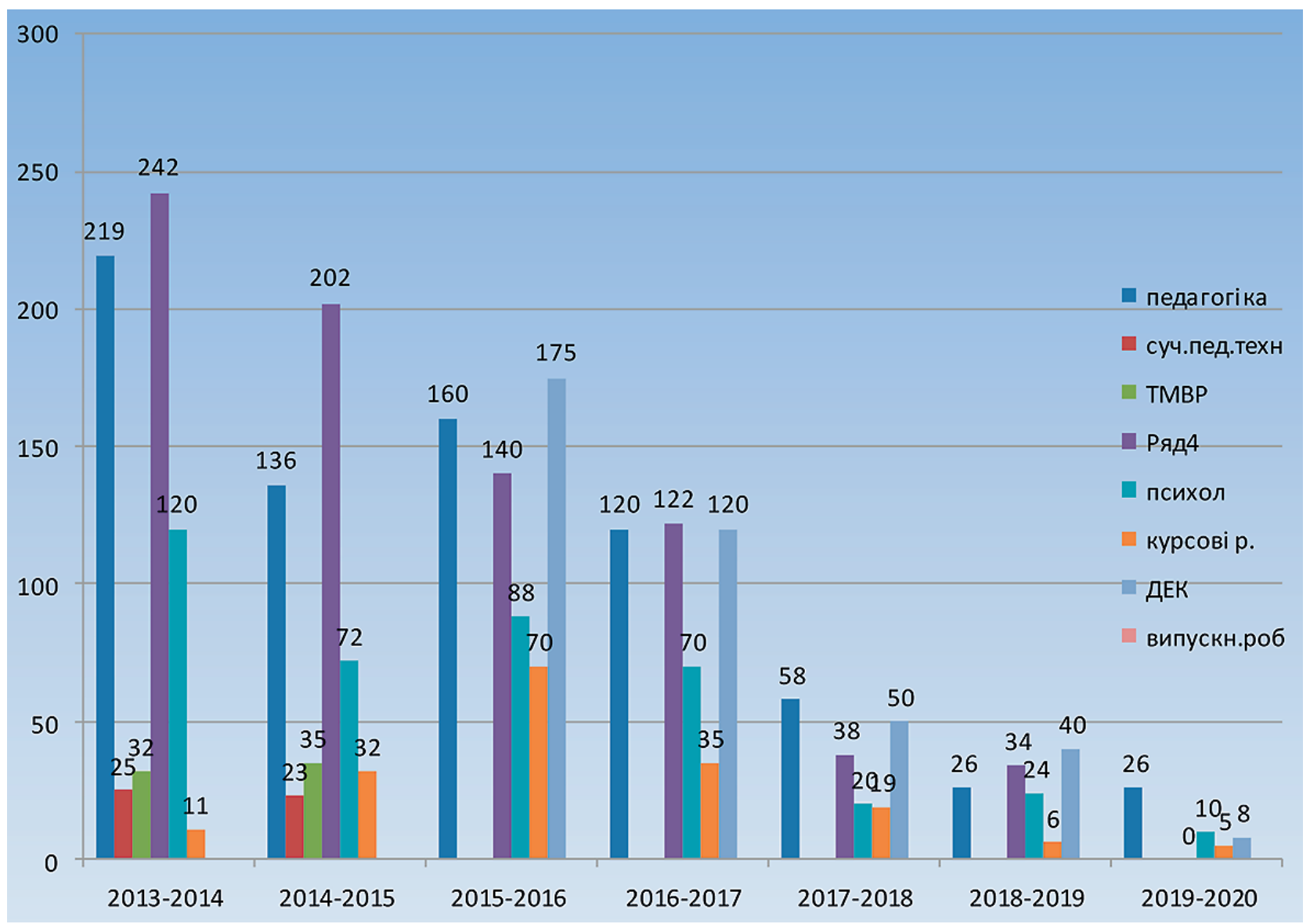

Діаграма. Структура та обсяг педагогічних дисичилін у професійній підготовиі вчителя в Херсонському державному університеті (2013-2020 роки) 
В означеному контексті важливим є використання i різних педагогічних ситуацій, їх моделювання та недопущення в майбутньому класним керівником, організатором виховної роботи в закладі освіти.

Важливу роль у цьому складному процесі відіграють форми роботи із засвоєння практичних умінь через аналіз виховних ситуацій, планування, організацію й проведення виховних заходів безпосередньо в аудиторії через систему рольових ігор, моделювання різних ситуацій, шляхів проведення виховного заходу, що сприятиме оволодінню майбутніми вихователями навичками самоаналізу, самоорганізації, комунікації, взаємодії з учасниками освітнього процесу, успішному розв’язанню професійних дій, досягненню поставленої педагогічної мети.

На продовження такої роботи спрямовується наступна складова педагогічної підготовки - організація виховної діяльності під час виробничої практики в школі. Студенти, працюючи в окремих класах, набувають навичок роботи класного керівника за відповідним планом (доповнюють план виховної роботи власними творчими пропозиціями), проводять заходи загальношкільного масштабу: конференції, свята, інтелектуальні ігри та змагання, мистецькі та спортивні заходи, відвідують з учнями театри, музеї, виставки із подальшим обговоренням $з$ дітьми та самоаналізом проведеного тощо.

Така безпосередня робота в умовах школи, закладу освіти сприяє формуванню основ педагогічної майстерності, розвиває творчі, конструктивні, комунікативні навички, організаторські вміння.

Також слід наголосити, що грунтовній професійній підготовці з питань виховної роботи 3 дітьми сприяє безпосередня участь студентів у позааудиторній роботі, до яких ми відносимо: тематичні кураторські години, мистецькі конкурси та спортивні турніри, майстер-класи, роботу клубів, проведення квестів, конференцій, заходів науково-дослідницького спрямування, що сприяє формуванню і соціалізаційної компетентності тощо.

Отже, процес організації педагогічної роботи, наприклад виховної, має бути неперервним, послідовним, відбуватися протягом усього терміну навчання, чітко визначатися навчально-освітніми програмами і планами, включати всі складові вивчення педагогіки через виокремлення навчальних модулів «Загальна педагогіка», «Історія педагогіки», «Теорія і практика виховання», «Освітній менеджмент», та доповнюватися дисциплінами за вибором професійного спрямування кожного факультету, що сприятиме підготовці вчителя сучасної школи. Таким чином, це буде 6 компонентів у загальному вивченні й засвоєнні основ підготовки до практичної діяльності: теоретичний блок модулів, поєднаних собою як за змістом, так і формою проведення із використанням бінарного, компетентнісного підходів за умов класичного (академічного) та змішаного навчання; практичний, який зреалізовується в умовах університетської освіти в освітньому середовищі відповідного закладу, факультету, кафедри; позааудиторна робота в культурно-освітньому та науково-творчому середовищі за інтересами студентів, зокрема і професійними; вивчення окремих авторських навчальних курсів професійного спрямування, виробнича практика. Наголошуємо, що важливе місце на завершальному етапі посідає виконання випускної кваліфікаційної роботи, яка, на наше переконання, має бути виконана як результат вивчення досвіду роботи школи, вчителя, класного керівника $з$ того чи іншого питання, що поєднує в собі всі складові навчання і виховання дітей. Таким чином, важливо проходити пропедевтичну (першу) практику, навчальну (2, 3 курси), виробничу і переддипломну $(4,5$ курси) в одному й тому ж закладі освіти, визначитися 3 темою кваліфікаційної роботи після 3-го курсу і завершити ії під час проходження педагогічної практики останнього року навчання за освітнім рівнем «бакалавр», що загалом унеможливить допущення академічного плагіату, а педагогічні знання будуть системними і базуватимуться на принципах неперервності, наступності, послідовності, покроковості, компетентності.

Висновки. Отже, дослідження підтвердило, що в підготовці вчителя важливими є інновації, але без вивчення і врахування історичного досвіду у підготовці фахівця ми не досягнемо бажаного успіху. А для цього необхідно:

1) забезпечити безперервний процес підготовки вчителя із щорічним викладанням педагогічних дисциплін, посиливши увагу до практичної підготовки;

2) формувати вибіркові навчальні дисципліни для вчителів за кожною спеціальністю, запропонувавши бінарні форми організації навчання на міжпредметній основі;

3) не уніфікувати загальні, вибіркові, професійні компоненти в закладі освіти, а закладати їх в освітні програми кожного факультету з чітким уточненням компетентностей, які вони формують саме у професійній підготовці вчителя за профілем;

4) викладаючи педагогічні дисципліни, виходити 3 того, що тільки творчий учитель може виховати творчого учня; вибудовувати освітній процес на педагогіці партнерства та творчості;

5) постійно працювати над введенням широкої палітри вибіркових дисциплін із педагогіки, долучивши студентів до визначення їх тематики, змісту через організацію науково-творчих об'єднань студентів.

Удосконалення вимагає і практична підготовка вчителя, в якій важливу роль відіграють навчальні дисципліни психолого-педагогічного, методичного, організаційно-педагогічного блоку, а можливо, і введення курсу «Педагог-організатор».

Перспективи подальших досліджень. Науковий пошук свідчить, що вивчення дисциплін педагогічного циклу у професійній підготовці вчителя - не лише архіважливий у контексті поєднання історизму й інноватики для науковців, а й окремий напрям досліджень. Його вивчення спрямовує на подальший науковий пошук, зокрема вимагає аналізу методика реалізації педагогіки партнерства у системі вищої освіти.

\section{СПИСОК ВИКОРИСТАНОЇ ЛІТЕРАТУРИ}

Кравець, В. Зарубіжна школа і педагогіка ХХ століття: навчальний посібник. (1996). Тернопіль. 290 с.

Вища педагогічна освіта і наука України: історія, сьогодення та перспективи розвитку. (2010) / за ред. Ю. І. Бєлясва. Київ: Знання України. 447 с

Програми педагогічних інститутів. Педагогіка. (1963). Київ: Радянська школа. 54 с.

Программы педагогических институтов. Генезис и основы педагогической системы А. С. Макаренко. (1986) / ред. А. И. Пискунов. Москва. 30 с. 
Программы педагогических институтов. (1985).

Программы педагогических институтов. Введение в учительскую специальность. (1978). Москва: Просвещение. 14 с.

Программы педагогических институтов. (1975).

Программа и типовая инструкция по организации и проведению педагогической практики студентов / ред. А. И. Юдина. Москва: Просвещение. 24 с.

ХДУ. Ф. 469. Оп. 9. Спр. 432.

Збірка авторських навчальних програм з психолого-педагогічних дисциплін. (2014). Херсон. 96 с.

Болонський процес: хрестоматія. (2005). Херсон: Видавництво ХДУ. 276 с.

Вітвицька, С. С. (2005). Основи педагогіки вищої школи. Київ: Либідь. 256 с.

Вступ до педагогічної професії: програма. (1985). Київ. 24 с.

Джуринський, О. М. (2014). Порівняльна педагогіка: підручник для ВНЗ. Москва: Академія.

Дубасенюк, О. А., Антонова, О. С. (2012). Методика викладання педагогіки: навчальний посібник. 2-ге вид., доп. Житомир: Вид-во ЖДУ ім. І. Франка. 375 с.

Історія педагогіки: методичні вказівки для самостійного вивчення курсу студентами-заочниками педінститутів. (1972). Київ: Вища школа. 88 с.

Карпенчук, С. Г. (2005). Теорія і методика виховання: навчальний посібник. Київ: Вища школа.

Кравець, В. П. Історія класичної зарубіжної педагогіки і шкільництва: навчальний посібник. (1996). Тернопіль. 436 с.

Кравець, В. П. (1994). Історія української школи і педагогіки: курс лекцій. Тернопіль. 360 с.

Педагогіка школи. Консультації та методичні вказівки до вивчення окремих тем з теорії виховання. (1973). Київ. 88 с.

Програми педагогічних інститутів. Bcmyn до педагогіки. (1977). Київ: Вища школа. 12 с.

Програми педагогічних інститутів. (1972). Встуn до педагогіки. Консультації для студентів-заочників педагогічних інститутів. Київ: Вища школа. 80 с.

Програми педагогічних інститутів. (1971). Bcmyn до педагогіки. Методичні вказівки до самостійного вивчення курсу студентами-заочниками педагогічних інститутів. Київ: Вища школа. 48 с.

\section{REFERENCES}

Kravets, V. (1996). Zarubizhna shkola i pedahohika KhKh stolittia [Foreign school and pedagogy of the XXth]: navchalnyi posibnyk. Ternopil. 290 s. [in Ukrainian].

Vyshcha pedahohichna osvita i nauka Ukrainy: istoriia, sohodennia ta perspektyvy rozvytku [Higher pedagogical education and science of Ukraine: history, present and prospects of development]. (2010) / za red. Yu. I. Bieliaieva. Kyiv: Znannia Ukrainy. 447 s. [in Ukrainian].

Prohramy pedahohichnykh instytutiv. Pedahohika [Programs of pedagogical instituions. Pedahohika]. (1963). Kyiv: Radianska shkola. 54 s. [in Ukrainian].

Prohrammy pedahohycheskykh ynstytutov. Henezys y osnovy pedahohycheskoi systemy A. S. Makarenko [Programs of pedagogical institutes. Genesis and basics of the pedagogical system Makarenko A.S.]. (1986). / red. A. Y. Pyskunov. Moskva. 30 s. [in Russian].

Prohrammy pedahohycheskykh ynstytutov [Programs of pedanonic institutes]. (1985). [in Russian].

Prohrammy pedahohycheskykh ynstytutov. Vvedenye $\mathrm{v}$ uchytelskuiu spetsyalnost [Programs of pedanonic institutes. Introduction to the teacher profession]. (1978). Moskva: Prosveshchenye. 14 s. [in Russian].

Prohrammy pedahohycheskykh ynstytutov. Prohramma y typovaia ynstruktsyia po orhanyzatsyy y provedenyiu pedahohycheskoi praktyky studentov [Programs of pedagogical institutes. Program and standard instructions for organizing and conducting pedagogical practice of students]. (1975). / red. A. Y. Yudyna. Moskva: Prosveshchenye. 24 s. [in Russian].

KhDU [Kherson State University]. F.469. Op. 9. Spr. 432. [in Ukrainian].

Zbirka avtorskykh navchalnykh prohram z psykholoho-pedahohichnykh dystsyplin [Collection of author's educational programs on psychological and pedagogical disciplines]. (2014). Kherson. 96 s. [in Ukrainian].

Bolonskyi protses [Bologna process]: khrestomatiia. (2005). Kherson: Vydavnytstvo KhDU. 276 s. [in Ukrainian].

Vitvytska, S. S. Osnovy pedahohiky vyshchoi shkoly [Fundamentals of higher pedagogy]. (2005). Kyiv: Lybid. 256 s. [in Ukrainian].

Vstup do pedahohichnoi profesii [Introduction to the teacher profession]: prohrama. (1985). Kyiv. 24 s. [in Ukrainian].

Dzhurynskyi, O. M. (2014). Porivnialna pedahohika [Comparative pedagogy]: pidruchnyk dlia VNZ. Moskva: Akademiia. [in Ukrainian].

Dubaseniuk, O. A., Antonova, O. Ye. (2012). Metodyka vykladannia pedahohiky [Methods of teaching pedagogy]: navchalnyi posibnyk. 2-he vyd., dop. Zhytomyr: Vyd-vo ZhDU im. I. Franka. 375 s. [in Ukrainian].

Istoriia pedahohiky [History of Ukrainian school and pedagogy]: metodychni vkazivky dlia samostiinoho vyvchennia kursu studentamy-zaochnykamy pedinstytutiv. (1972). Kyiv: Vyshcha shkola. 88 s. [in Ukrainian].

Karpenchuk, S. H. (2005). Teoriia i metodyka vykhovannia [Theory and methods of education]: navchalnyi posibnyk. Kyiv: Vyshcha shkola. [in Ukrainian].

Kravets, V. P. (1996). Istoriia klasychnoi zarubizhnoi pedahohiky i shkilnytstva [History of classical foreign pedagogy and schooling]: navchalnyi posibnyk. Ternopil. 436 s. [in Ukrainian].

Kravets, V. P. (1994). Istoriia ukrainskoi shkoly i pedahohiky [History of Ukrainian school and pedagogy]: kurs lektsii. Ternopil. 360 s. [in Ukrainian].

Pedahohika shkoly [School pedagogy]: konsultatsii ta metodychni vkazivky do vyvchennia okremykh tem z teorii vykhovannia. Kyiv. 1973. 88 s. [in Ukrainian].

Prohramy pedahohichnykh instytutiv [Programs of pedagogical institutes]. (1977). Vstup do pedahohiky. Kyiv: Vyshcha shkola. 12 s. [in Ukrainian].

Prohramy pedahohichnykh instytutiv [Programs of pedagogical institutes]. (1972). Vstup do pedahohiky. Konsultatsii dlia studentiv-zaochnykiv pedahohichnykh instytutiv. Kyiv: Vyshcha shkola. 80 s. [in Ukrainian].

Prohramy pedahohichnykh instytutiv [Programs of pedagogical institutes]. (1971).Vstup do pedahohiky. Metodychni vkazivky do samostiinoho vyvchennia kursu studentamy-zaochnykamy pedahohichnykh instytutiv. Kyiv: Vyshcha shkola. 48 s. [in Ukrainian].

Дата надходження до редакиіï: 26.06.2021 p. 